\title{
Content Analysis on Energy Issues in Kompas Daily
}

\author{
Yanuar Luqman ${ }^{1, a)}$ \\ ${ }^{1}$ Communications Department, FISIP Diponegoro University \\ a) yanuar@undip.ac.id
}

DOI: https://doi.org/10.18196/ikm.111020

Article Info

Article history:

Received 28 Jan 2019

Revised 22 March

2019

Accepted 7 May 2019

\section{ABSTRACT}

The energy sector plays a very strategic role in Indonesia's government as opposed to infrastructure, food, education, health, and social protection. Energy issues are related to political, economic, social, and cultural aspects. The government, in its national energy policy, manages the energy based on the principles of justice, sustainability, and environmental perception in order to create national energy independence and security. To create national energy independence and security, the government needs the participation of community and media. Media has a role in establishing public agenda to support the government's policy in the energy sector. The role of mass media, in this case, is building public awareness about the importance of the energy sector because it is not only for a short-term benefit but also for sustainable development. This research describes how the media deliver information about energy issues in Indonesia. The basic theory used in this research is the agendasetting theory that is complemented by other supporting theories. By using quantitative descriptive content analysis research type, the issues on energy are seen using: technical, rubrication, writing style, writing technique, and interviewee selection indicators. Kompas daily newspaper is the study subject in this research because it is relatively consistent in editorial policy. The samples used are taken from January - May 2018 edition. The results show that Kompas Daily had not played many roles in energy problems from various aspects.

Keywords: content analysis, energy, KOMPAS, media

\section{ABSTRAK}

Sektor energi memiliki peran yang sangat strategis dalam pemerintahan Indonesia selain infrastruktur, makanan, pendidikan, kesehatan, dan perlindungan sosial. Masalah energi terkait dengan aspek politik, ekonomi, sosial dan budaya. Pemerintah, dalam kebijakan energi nasionalnya, mengelola energi berdasarkan prinsip keadilan, keberlanjutan, dan persepsi lingkungan untuk menciptakan kemandirian dan keamanan energi nasional. Dalam upaya menciptakan kemandirian dan keamanan energi nasional, pemerintah membutuhkan partisipasi masyarakat dan media. Media memiliki peran dalam menetapkan agenda publik untuk mendukung kebijakan pemerintah di sektor energi. Peran media massa, dalam hal ini, adalah membangun kesadaran publik tentang pentingnya sektor energi karena tidak hanya untuk keuntungan jangka pendek, tetapi juga untuk pembangunan berkelanjutan. Penelitian ini menggambarkan bagaimana media menyampaikan informasi tentang masalah energi di Indonesia. Teori dasar yang digunakan dalam penelitian ini adalah teori agenda setting dan dilengkapi dengan teori-teori pendukung lainnya. Dengan menggunakan, jenis penelitian analisis konten deskriptif kuantitatif, masalah energi dilihat dengan: teknis, rubrik, gaya penulisan, teknik penulisan, dan pemilihan orang yang diwawancarai. indikator. Koran harian Kompas adalah subjek penelitian dalam penelitian ini karena relatif konsisten dalam kebijakan editorial. Sampel yang digunakan adalah edisi Januari - Mei 2018. Hasil penelitian menunjukkan bahwa Harian Kompas tidak banyak berperan dalam masalah energi dari berbagai aspek.

Kata kunci : content analisis, energi, KOMPAS, media 


\section{INTRODUCTION}

Energy independence and security is a strategic issue in which energy consumption dependence towards fossil fuels (oil and gas) has the potential to cause a crisis. Data derived from Asian Development Bank (2015) demonstrate that in 2004, actually, the energy crisis has begun especially in the oil sector. The crisis occurred because the energy balance generally showed the energy consumption growth of +3.9 percent, which was inversely proportional to the total energy production of -10.6 percent (BP 2016). The threat of crisis also relates to the energy mix used. Most of the energy production comes from fossil energy, 31.49 percent for oil, 24.82 percent for coal and 19.04 percent for gas (MEMR 2016), while the new and renewable energy is only 7.5 percent (Sugiyono, 2016)

The data from the International Energy Agency (2017) stated that Indonesia is the largest energy consumer in Southeast Asia, which is more than 36\% of primary energy use in Southeast Asia. Between 2000 and 2015, Indonesia's gross domestic product (GDP) doubled, and the electricity demand increased by $150 \%$. Economic growth drives Indonesia's energy needs. It is estimated that the additional capacity of electricity of 4.1 gigawatts (GW) is needed per year until 2030, of which 50\% comes from the coal power plant. Efficiency is critical to saving energy and costs as well as to reduce emissions.

Energy issues which cannot be separated from the environmental aspects relating to the paradigm of sustainable development is a theme that is always discussed when dealing with the environment. Sustainable development is an effort to synchronize, integrate, and give equal weight to three main aspects of development, namely economic, socio-cultural, and environmental aspects (Keraf 2005). Those three aspects of development must be viewed as elements that are strictly related to one another so that the elements are interrelated and inseparable or not contradictory. In sustainable development, the emphasis is not only on economic aspects but also on socio-cultural and environmental aspects.

Media are essential tools in environmental education. The discussions concerning environmental concepts and awareness are very new developments. There is not enough space specialized to the media for environmental topics. There is a tendency to approach environmental issues from an alarmist perspective rather than a scientific one (Ors, 1339: 2012). The mass media has a significant role in building awareness about the energy crisis. Kompas, on Thursday, March 5th, 2015 reported that Indonesia is estimated, in the next 11 years, would run out of petroleum reserves. To anticipate the energy crisis, it needs the awareness of the community and the government to make concrete, systematic, and structured breakthroughs in energy-saving efforts and to develop non-fossil energy.

The caring attitude of the mass media (press) on energy issues is needed to contribute more or support the efforts to anticipate the energy crisis. The character of the press contents includes the elements of closeness and emotions that touch human needs, namely energy. The reality of the energy condition is the primary raw material for news about energy issues which are informed by the press as a manifestation of the role of media towards energy issues.

Kompas became the object of research because it is a national daily newspaper which is classified as a high quality and high business performance newspaper. It is expected that it can contribute significantly to solving energy issues, especially in Indonesia. This study aims to describe how Kompas in reporting energy issues in several ways and points of view.

Concept review: Shanahan wrote about Media Portrayal of Energy (2004: 9) that Mass media play a role in describing energy issues. Since the energy crisis in 1973, the attention of scholars has changed to how the media forms, frames, and the influence of viewers' perceptions of energy and the environment are. During the period after the energy crisis, especially during the 1980s and early 1990s, energy conservation issues were often becoming the topic of concern for scientists. The oil crisis and the perceived dangers of nuclear power made people sensitive to the importance of energy savings. These issues were also often mentioned in the media.

At the beginning of this environmental movement, it was believed that mass media could become a prominent tool to encourage energy conservation by implementing the energy saving steps and promoting the alternative use of energy sources. The fact is that the media can play an essential role in one's choice. Influences such as advertising, journalism, television programs, and other media need to be considered when determining how people make choices in energy use behavior.

The media should inform an event which has broad, honest, and objective news values in the framework of fulfilling the public's right to obtain the information needed. However, on the other hand, the concept of the Media Agenda allows the media to choose, conduct selection, and determine 
what information will be processed and presented to meet its public needs. Choice and media attention to a particular phenomenon ultimately lead to the formation of a tendency called bias (Mc. Quail in Shoemaker and Reese, 2014: 42).

Agenda-setting model states that the media determine what is given to the public and consider that the thing given is worth listening to the people (Littlejohn et al., 2017: 162). The function of the agenda-setting of the mass media is a concept that determines the positive relationship between the importances of the issue among the public. The media always have full power if the media credibility is high, conflicting information is low, and the value of personal media sharing and the audience has a high need for guidance (Littlejohn et al., 2017: 163). Kompas has an agenda on energy issues which have editorial policies, including ways, styles, work orientation, and levels of contribution to energy issues. In this case, it is expected that Kompas agenda which contains energy independence and security compiled by editors can positively influence the public so that the public agenda which arises will recognize the importance of maintaining energy independence and security.

In this research, Kompas is considered as having a function in its efforts to contribute to energy issues understanding. Lasswell in Littlejohn \& Foss (2009: 575) identified three main functions of mass media:

1. Environmental monitoring: is carried out by delivering messages as a preventive effort in the context of energy independence and security from the threat of energy crisis.

2. Correlation between sections of society: is carried out by selecting, conducting interpretation, and criticizing information relating to energy issues to be transmitted to the public so that the issues can be adequately responded.

3. Transmission of social heritage: is an effort in communicating values, norms, and time section and inter groups' styles. Newspapers have functioned as both windows which enter to culture and other contemporary time capsules for future generations - distributing information about energy independence and security to become a social institution and to be useful for the next generation.

\section{METHOD}

The type of this research is descriptive quantitative using content analysis methods. Krippendorff (2004: 18) defined that content analysis is a research method used to make conclusions that can be replicated and validated from the text in the context of its use. Content analysis is used to describe the contents of a manifest communication text. Manifestation in content analysis refers to visible and explicit communication texts (Drisco \& Maschi, 2016: 2).

The sample of this research was energy-themed news that was published in Kompas Newspaper from January to May 2018. Reliability test was conducted to fulfill the aspect of goodness criteria using intercoder reliability ( 3 coders) using Pearson Correlation formula. The results of the intercoder reliability, which has been performed, showed a value of 84.5 so this research instrument could be stated reliable.

The coding process was carried out by looking at the data regarded in the news based on the technical category, rubric space, style of writing disclosure, writing techniques, and the selection of interviewees.

\section{ANALYSIS}

The results of this research are started by discussing on the technical side. Kompas Newspaper, in reporting on energy issues, provided a sufficient portion. This can be seen in Diagram 1 that from the frequency calculation of centimeters per column, $46 \%$ ranged from 5 to 41 , and $30 \%$ ranged from 42 to 78 centimeters column. The news concerning energy issues was mostly (74\%) published on pages 11 to 20 (see Diagram 2) which means that energy issues had not yet gained a strategic position. 


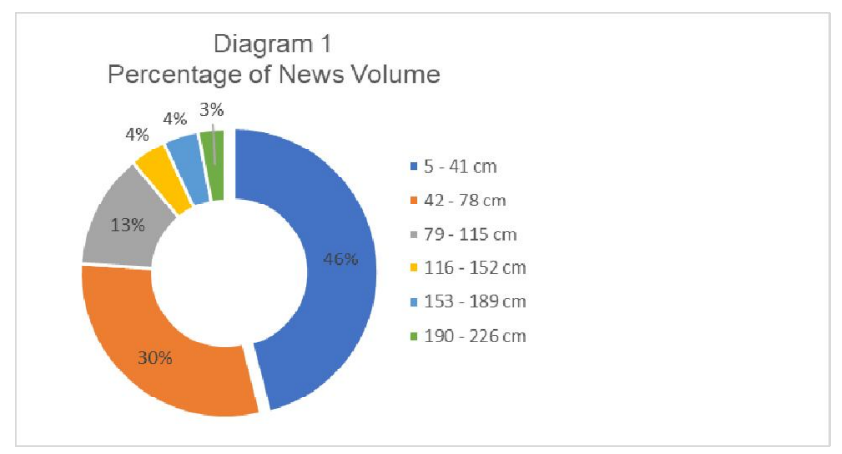

Diagram 1. News Volume

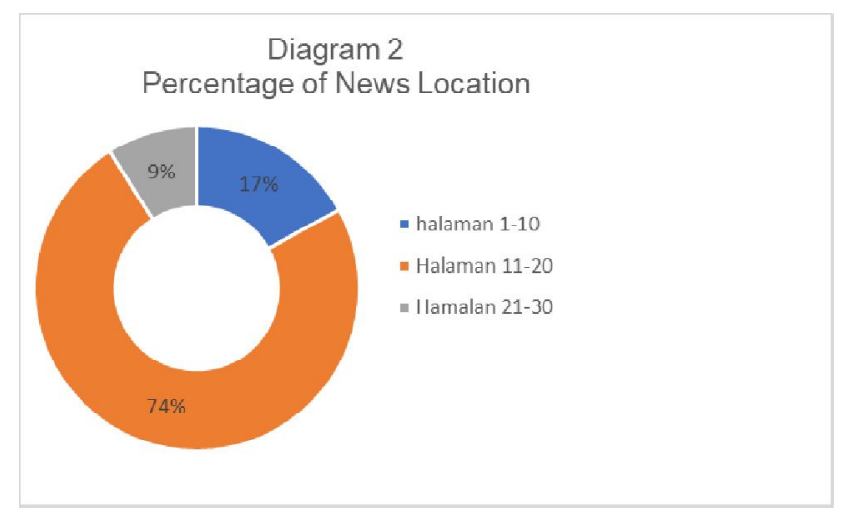

Diagram 2. News Location

Energy issues can be divided into various themes (Diagram 3). In Kompas Newspaper, the theme that often obtained a place is news concerning price or economic level $(28 \%)$ and environmental impact due to energy consumption (24\%). Energy crisis and non-oil and gas energy development did not obtain a large portion. On the other hand, (Diagram 4) the news concerning energy issues in Kompas Newspaper was more likely to choose what (65\%) news angle.

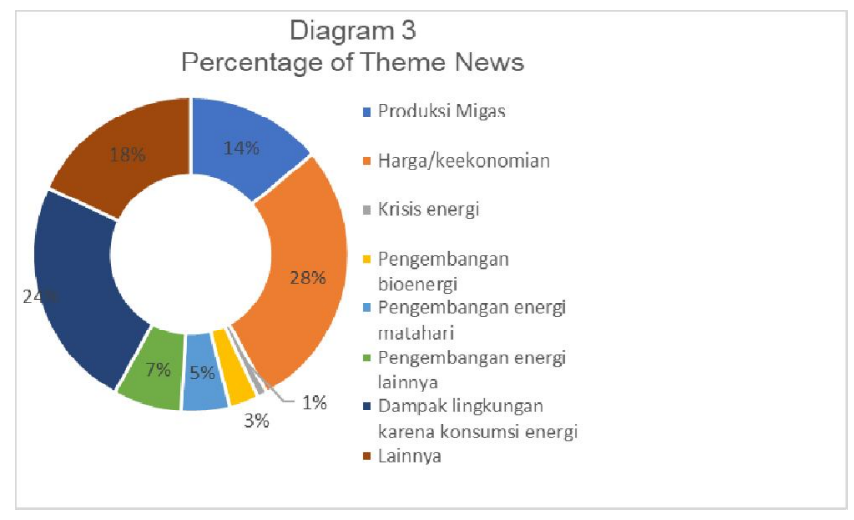

Diagram 3. Theme of News 


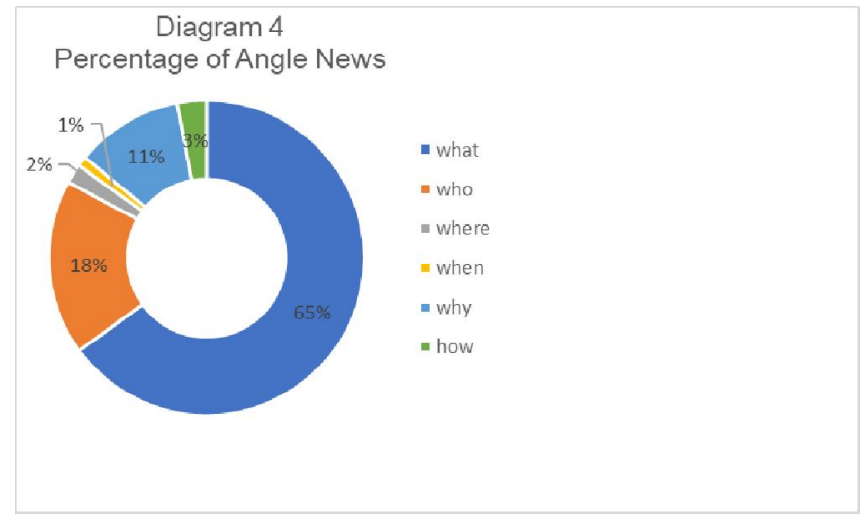

Diagram 4. Angle of News

The news about energy issues had not yet gained a significant place in Kompas Newspaper. In Diagram 5, it is shown that most of the news concerning energy issues in Kompas Daily was included in the $32 \%$ of main news category and $41 \%$ of the common news while the headline placement was only $4 \%$. Energy issues were in line with the news theme data in Diagram 3, the economic rubric $(71 \%)$ became a place which was often used to place news concerning on energy issues in Kompas Newspaper (see Diagram 6).

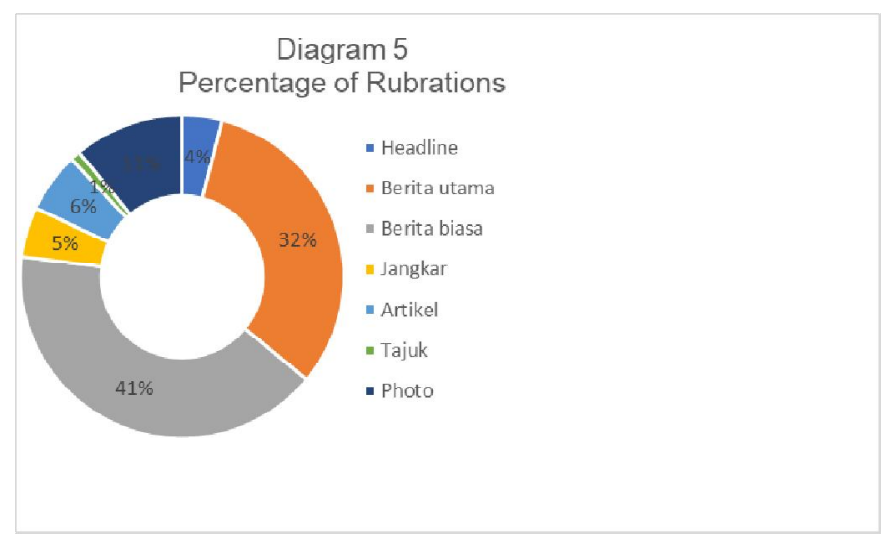

Diagram 5. Rubrations

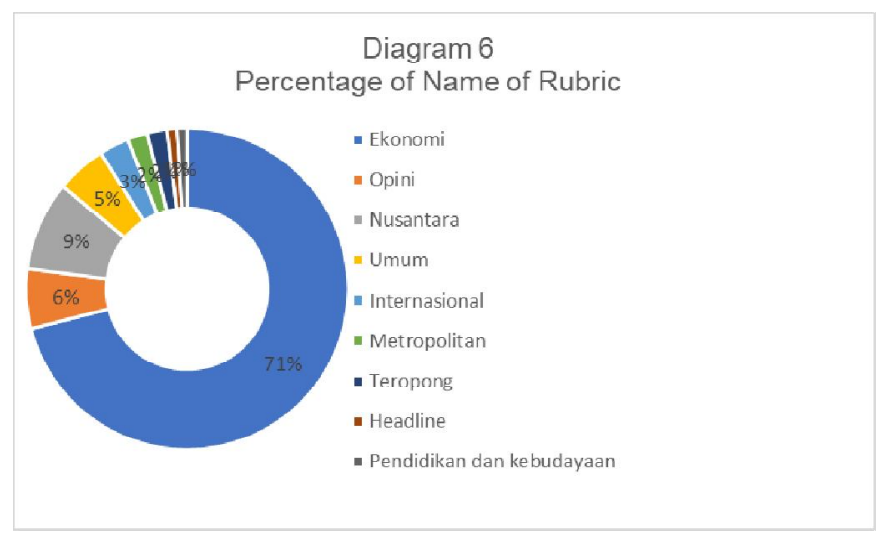

Diagram 6. Name of Rubric 
In the aspect of news writing, this research paid attention to the title and content writing style. In Diagram 7, it can be seen that most of Kompas Newspaper wrote the subtitles substantially (93\%). The title was written with straightforward, smooth, or direct word choices to understand its meaning so that it can be concluded that whether it represents partiality or neutrality. In Diagram 8, it can be seen that most of Kompas Newspaper wrote the title descriptively (95\%). Descriptions of reported events were delivered straightforwardly with simple language style which was easily understood by most people, and it exposed events as news in the $5 \mathrm{w}$ and $1 \mathrm{H}$ element.

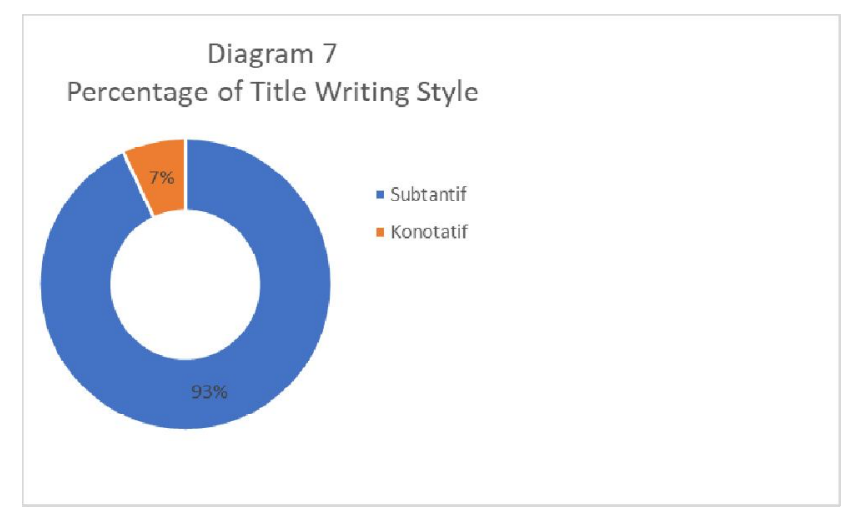

Diagram 7. Title of Writing Style

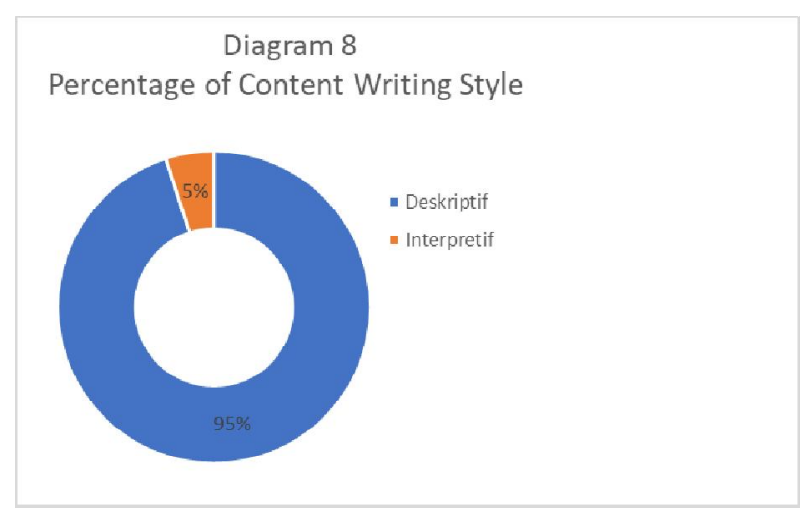

Diagram 8. Content of Writing Style

Diagram 9 illustrates that, in reporting energy issues, Kompas Newspaper was presented with straight and investigative writing techniques, 50\% respectively. The type of interviewee as illustrated in Diagram 10, which was widely cited as news sources in this research, was mostly sourced from bureaucrats (35\%), BUMN (State-Owned Enterprises) and Private (28\%) and intellectuals (27\%).

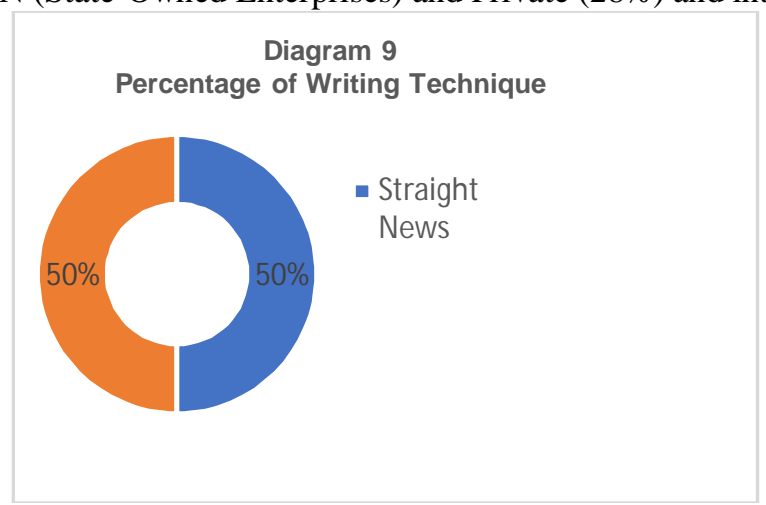

Diagram 9. Technique of Writinng 


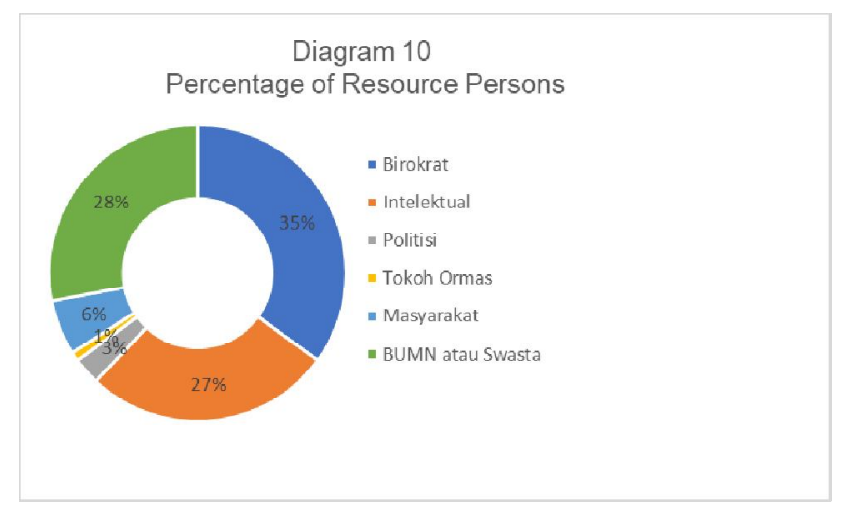

Based on the Agenda Setting theory, it is stated that the media have the ability to determine what will be given to the public and assume that the things given are worthy of being accepted by the public. In reporting energy issues, Kompas Newspaper had a technical role that was not optimal. Energy issues, in the Kompas Newspaper, were not given sufficient space not granted a strategic position. The volume which was not wide enough and the news lying mostly showed that Kompas Newspaper had not seen the energy issues to be vital agenda that demanded the attention of all parties.

The tendency of the theme of energy issues in Kompas Newspaper highlighted price/economy and environmental impact more because energy consumption showed that Kompas Newspaper carried out the functions of mass media in the context of environmental monitoring and correlation. The theme of the energy crisis and the development of non-fossil energy have not received sufficient portions which indicate that the Kompas Newspaper has not carried out the transmission function. Energy issues covered multi-aspect problems and are related to sustainable development. In addition to economic aspects and environmental impacts, it is necessary for the aspects of solutions in solving energy issues to be scheduled or planned.

Energy issues are complex problems. Energy is related to the upstream and downstream aspects. The presentation of the news that tends to "what" news angle showed that Kompas Newspaper had not elaborately presented news of energy issues. It means that the news was intentionally written to highlight aspects of events or phenomena that were considered significant. It could be due to either reason of high attractiveness, significant value to the audience, or newness (actuality) only. Consistent with the aspect of the news volume and the location of the news, Kompas Newspaper placed more news on energy issues in the common news section (inner page), especially the economic rubric. The findings correspond with the understanding of the government (decision makers) that regards energy in the aspect of the crisis with a focus on the economy (Luqman et al., 2018: 90).

The categories used to review news headings were made dichotomically; substantive, and connotative. With the substantive category, it means that the news title was written with straightforward word choices, smooth, or directly understandable so that from this title, it can be interpreted whether the content of the news title represents partiality or neutrality. With the connotative category means the writing of the news title was performed with a choice of words in the form of expressions, presuppositions, euphemisms, or other words that had a double meaning so that it was difficult to identify whether it was siding or neutral.

Not different from the disclosure style of the title, the category for this content disclosure style was also mapped dichotomically; descriptive, and interpretive. In Descriptive Style, the depictions of events reported were conveyed straightforwardly, with language styles and word choices that were easily understood by most people. With this kind of style, neutrality or partiality of news was more easily recognized. On the contrary, the Interpretive Style of exposure regarding the events reported was carried out by loading the elements of weighing, analytics, not straight to the point, so that they were not easily recognized whether they were siding or neutral.

The selection of sources of the news which were mostly sourced from bureaucrats and BUMN (state-owned enterprises) or private as well as intellectuals showed that Kompas Newspaper tends not to side with society. People had not been allowed to play a more significant role in energy discourse. 


\section{CONCLUSION}

Kompas Newspaper, in reporting energy issues, has not provided enough space and placed the news in a strategic position. The news was placed on common news (economic rubric). In line with the rubrication, short-term interests were prioritized by Kompas Newspaper by highlighting the economic agenda rather than the solution to solve energy issues.

Considering the importance and urgency of the energy issues, Kompas was expected to provide sufficient space and place of related news on a strategic location. The news should be expanded not only to focus on economic aspects but also to cover the solution aspects of energy issues, namely the development of non-fossil energy as a solution to energy issues.

The news was intentionally written to highlight the aspect of events or phenomena which were considered necessary. The title was written in a straightforward (substantive) manner with descriptive content. In addition, Kompas Newspaper had not provided space for the public to be involved in the discourse on energy issues.

Kompas newspaper should not ask to focus on the "what" aspect in the news writing. Expansion of aspect can be conducted so that the agenda which was formed can be transmitted fully by providing enough space for the community to be involved in the discourse.

\section{REFERENCES}

ADB. (2015). Summary of Indonesia's Energy Sector Assesment, ADB Papers on Indonesia. Manila : Asian Development Bank.

BP. (2016). Statistical Review 2016 Indonesia's energy market in 2015. Diakses dari http://www.bp.com/content/dam/bp/pdf/ energy-economics/ statistical-review-2016/bpstatistical-review-of-world-energy-2016-indonesia-insights.pdf

Drisco, J. \& Maschi, T. (2016). Content Analysis. New York: Oxford University Press

IEA. (2017). Energy Efficiency 2017, Laporan Khusus : Efisiensi Energi di Indonesia. France : International Energy Agency

Keraf SA. (2005). Etika Lingkungan. Jakarta, Kompas.

Krippendorff, K. (2004). Content analysis: an introduction to its methodology. Thousand Oaks, CA: SAGE Publications

Littlejohn, S.W., Foss, K.A. (2009). Encyclopedia of Communication Theory. Thousand Oaks. SAGE Publications

Littlejohn, S.W., Foss, K.A., Oetzel, J.G. (2017). Theories of Human Communication 11th ed.Long Grove. Waveland Press Inc.

Luqman Y. (2018). Konstruksi Komunikasi Kebijakan Publik Tentang Energi Terbarukan (Disertasi). Bogor. Institut Pertanian Bogor

MEMR. (2016), Handbook of Indonesia's Energy Economy Statistics. Jakarta. Ministry of Energy and Mineral Resources.

Ors F. (2012). Environmental education and the role of media in environmental education in Turkey. Procedia - Social and Behavioral Sciences $461339-1342$

Shanahan J. (2004). Encyclopedia of Energy, Volume 4. Elsevier Inc., 9-16

Shoemaker P J, Reese S D, (2014). Mediating the message in the 21st century: a media sociology perspective. Third edition. New York. Routledge

Sugiyono A, Anindhita, Wahid L, Adiarso. (2016). Outlook Energi Indonesia : Pengembangan Energi Untuk Mendukung Industri Hijau. Jakarta Pusat Teknologi Sumberdaya Energi dan Industri Kimia BPPT 